Portland State University

PDXScholar

1975

\title{
The morphology of the eye of the purple shore crab, Hemigrapsus nudus
}

Sharon E. Heisel

Portland State University

Follow this and additional works at: https://pdxscholar.library.pdx.edu/open_access_etds

Part of the Biology Commons

Let us know how access to this document benefits you.

\section{Recommended Citation}

Heisel, Sharon E., "The morphology of the eye of the purple shore crab, Hemigrapsus nudus" (1975). Dissertations and Theses. Paper 2163.

https://doi.org/10.15760/etd.2160

This Thesis is brought to you for free and open access. It has been accepted for inclusion in Dissertations and Theses by an authorized administrator of PDXScholar. Please contact us if we can make this document more accessible: pdxscholar@pdx.edu. 
AN ABSTRACT OF THE THESIS OF Sharon $E$. Heisel for the Master of Science in Biology presented May 21, 1975.

Title: The Morphology of the Eye of the Purple Shore Crab; Hemigrapsus nudus.

APPROVED BY MEMBERS OF THE THESIS COMMITTEE:

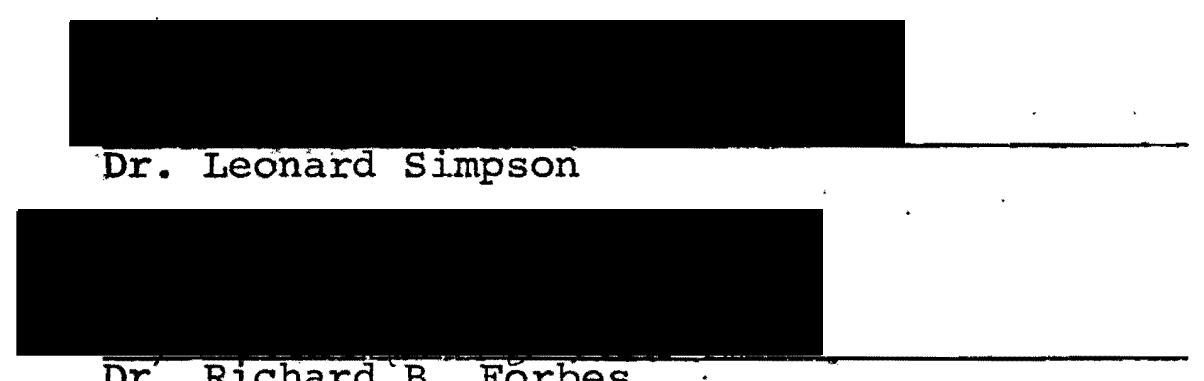

Dr. Richard B. Forbes
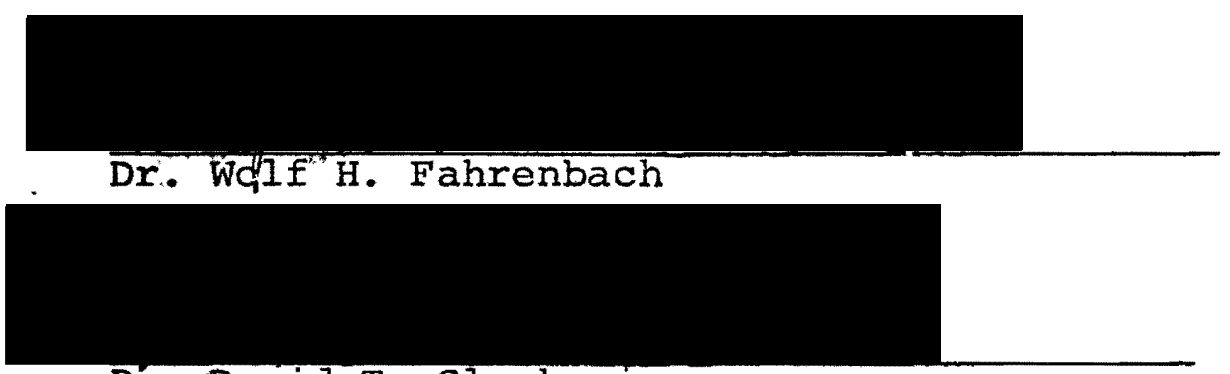

Dr. David T. Clark

A structural analysis of the compound eye of Hemigrapsus nudus expands the basis of functional analysis of decapod Crustacean eyes. Contradictory evidence for disintegration of rhabdomeric microvilli in the absence of light prompted observation of $\mathrm{H}$. nudus eyes after 146 days in darkness.

Eyes were fixed with formalin and glutaraldehyde and 
postfixed with osmium tetroxide for electron and light microscopy. Light- and dark-adapted eyes were also observed with hot water fixation and paraffin embedment. The eye of $\mathrm{H}$. nudus is typical of decapod Crustacean compound eyes. Corneagenous cells underlie the transparent cuticle. Four cone cells secrete the composite crystalline cone which contacts the rhabdom proximally. The single fused rhabdom is composed of layers of microvilli from two groups of retinular cells. The layers are oriented at right angles to each other, and perpendicular to the optic axis of the ommatidium. A presumptive four-lobed eighth retinular cell makes up the distal end of the rhabdom.

Distal, proximal and reflecting retinal pigments are located in the distal pigment cells, retinular cells and tapetal cells, respectively. Distal and proximal pigments surround the rhabdom during light-adaptation, and withdraw during dark-adaptation. Reflecting pigment is found above the basement membrane in light-adapted eyes and below it in dark-adapted eyes. The crystalline cone may change length during light- and dark-adaptation. Prolonged darkness does not cause disintegration of the rhabdomeric microvilli.

H. nudus lives in conditions of dim illumination. The fused, layered rhabdom is an efficient mechanism of light absorption. Internal reflection within the rhabdom 
is enhanced by the palisade and further increases light absorption.

Functional units exist within the ommatidium. Mutually perpendicular rhabdomeric layers suggest intraretinal polarized light perception: Eighth retinular cells may respond individually to light focused on the distal rhabdom by the dioptric apparatus resulting in mosaic image formation. 
THE MORPHOLOGY OF THE EYE OF THE PURPLE SHORE CRAB, Hemigrapsus nudus

\title{
by
}

SHARON E. HEISEL

A thesis submitted in partial fulfiliment of the requirements for the degree of

\author{
MASTER OF SCIENCE \\ in \\ BIOLOGY
}

Portland State University

1975 
TO THE OFFICE OF GRADUATE STUDIES AND RESEARCH:

The members of the Committee approve the thesis of Sharon E. Heisel presented May 21, 1975.

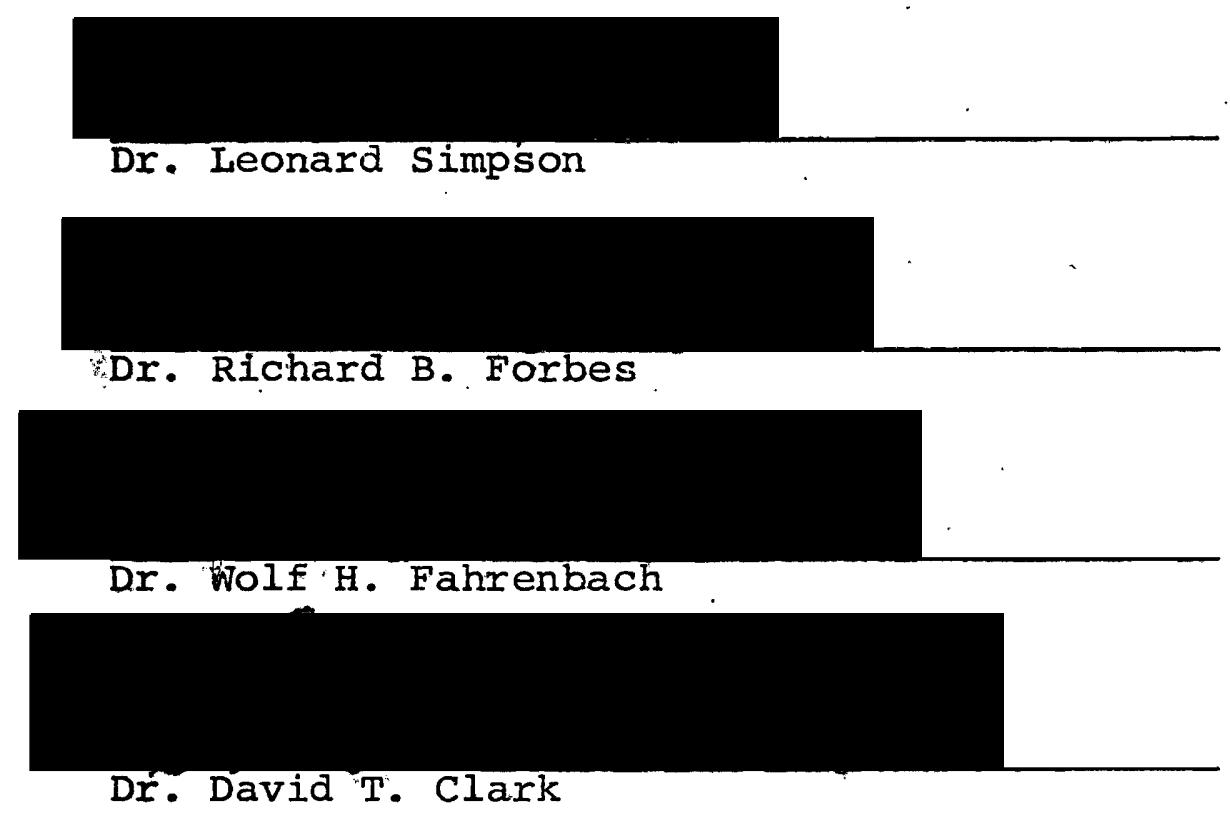

APPROVED:

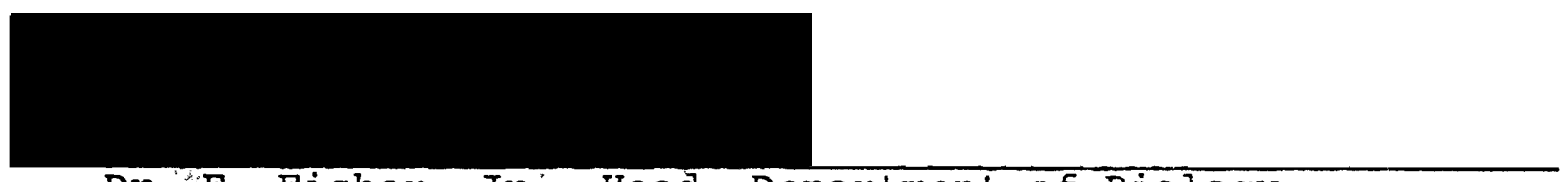

Dr."E. Fisher, Jr., Head, Department of Biology

Dr. Bavid T. Clark, Dean of Graduate Studies and Research

May 21, 1975 


\section{ACKNOWLEDGMENTS}

I am deeply grateful for the guidance and encouragement of the following three people:

Dr. Leonard Simpson, who opened the world of the invertebrates to me, and who set a compelling example of excellence.

Dr. Wolf H. Fahrenbach, who gave generously of his time, technical expertise, and assistance.

Manville M. Heisel, sine qua non. 


\section{PREFACE}

A general dermal light sense and discrete light receptors such as occelli are photoreceptive mechanisms which arthropods share with other phyla (Millot, 1968; Goldsmith, 1964). The compound eye is unique to this group.

As a simple model, the compound eye can be conceived as a cluster of cones with converging axes. Every cone is called an ommatidium and receives light from objects coincident with its optical axis. The extent and detail of the field viewed depends on the size and number of the cones (Wolken, 1971). This model is complicated by responsiveness between ommatidia (Shaw, 1969a; Goldsmith, 1964) and within ommatidia (Burkhardt, de la Molle and Seitz, 1966; Eguchi, Waterman and Akiyama, 1973; Waterman and Horch, 1966).

I. GENERAL CHARACTERISTICS OF ARTHROPOD COMPOUND EYES

Each compound eye consists of ommatidial units which are distinguished by facets on the eye surface. The distal portion of an ommatidium is the dioptric apparatus: the corneal lens (delineated by the facet) and the crystalline cone. The cuticle of the lens, which lacks the calcium 
deposits and pigment typical of other arthropod cuticle, is transparent. Underlying the corneal lens are usually four corneagenous cells which secrete it (Goldsmith, 1964). Proximal to the corneagenous cells are four cone (or, in insects, semper) cells. The cone cells give rise to a clear intraceliular secretion, which extends proximally from the lens and is either a hard or a fluid structure (Goldsmith, 1964). The dioptric apparatus concentrates light at the base of the crystalline cone (Burtt and Catton, 1966; Kuiper, 1966).

Proximal to the dioptric apparatus are from four to twenty neurosensory cells; the exact number is usually constant within a species. By analogy with the vertebrate retina, these retinular cells together compose the retinula. The retinular cells are arranged with their long axis parallel to the ommatidial axis, and on the edge near the ommatidial axis each retinular cell contributes microvilli to a composite axial structure, the rhabdom. This is the probable site of the photoreactive visual pigment (Eakin, 1972). Since the refractive index of the rhabdom is higher than that of the surrounding retinular cells, it acts as a wave guide (Kuiper, 1966).

A single layer of microvilli from a single retinular cell is called a rhabdomere. The microvilli are oriented at right angles to the optical axis of the 
ommatidium.

Proximaliy, retinular cells form axons which extend through the basement membrane (if present) to the most distal part of the optic lobe, the lamina ganglionaris. Pigment granules occur in most invertebrate photoreceptors (Eakin, 1972) and affect the amount of light which reaches the visual pigments. These granules may control light transmission between adjacent ommatidia, change the effectiveness of the wave guide mechanism, or slow.the decay of visual pigments in intense light (BuIlock and Horridge, 1965).

The above are generalizations. Various arthropod groups display consistent peculiarities of structure.

II. GENERAL CHARACTERISTICS OF DECAPOD COMPOUND EYES

The compound eyes of decapod Crustacea have several typical characteristics. There are seven or eight retinular cells. The eighth cell, if present, is unusual in structure or location since it may have no rhabdomere and is either far distal or far proximal. The seven other retinular cells are divided into two groups, with microvilli, from three of the cells always at right angles to microvilli from the remaining four. Layers of microvilli from one group alternate with layers from the other, with each group maintaining a given orientation (Eguchi and 
Waterman, 1966) (Fig. 1). The two groups of retinular cells are aligned with the vertical and horizontal axes of the animal at the center of the eye when it is held erect (Waterman, Fernandez and Goldsmith, 1969).

Crustacean ommatidia have three groups of accessory pigment granules: distal, in cells surrounding the crystalline cone; proximal, in retinular cells; and reflecting, in cells adjacent to the basement membrane (Kleinholz, 1966). The pigment granules migrate with variation in light intensity; how far and which group of granules depends upon the species. In Homarus americanus, for example, only the proximal pigment moves (Kleinholz, 1966). More typically, during light-adaptation the distal and proximal pigments approach each other and the reflecting pigment withdraws below the basement membrane.

Decapod eyes have a fused type of rhabdom in which microvilli from opposite rhabdomeres abut (Fig. 1). A final typical characteristic is the palisade, an aggregation of perirhabdomal vacuoles. The palisade is a striking feature of decapod Crustacea, and is apparently universal in brachyura (Eguchi and Waterman, 1966). It also occurs in some insects. 


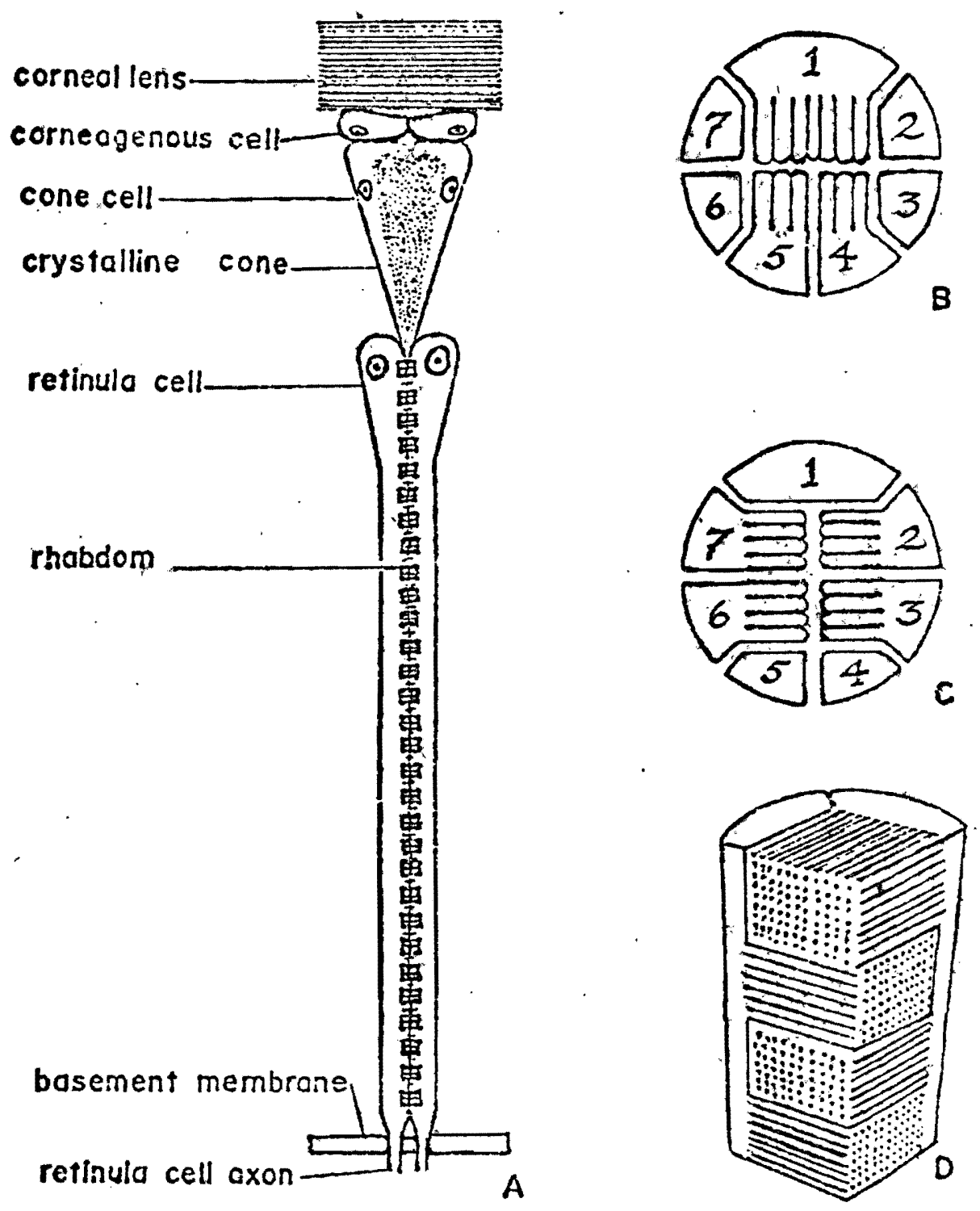

Figure 1. Diagramatic representation of the ommatidial structure of the typical decapod compound eye of Callinectes ornatus. A. Longitudinal section. through the optic axis. B. Cross-section through the rhabdom showing the make-up of one layer which is composed of three rhabdomeres: a double-sized rhabdomere from retinula cell 1 and two regular quarterrhabdom rhabdoneres from cells 4 and 5 . C. Crosssection of the adjacent rhabdom layer which has microvilli oriented at $90^{\circ}$ to those in $B$. This layer has rhabciomeres derived from retinula cells $2,3,6$, and 7 . D. Stereodiagram of the Jayered structure of the rhabdom. Adapted from Fguchi ard raterman (1966). 
TABLE OF CONTENTS

PAGE

ACKNOWLEDGMENTS

iii.

PREFACE ...................... . . iv

I. GENERAL CHARACTERISTICS OF ARTHROPOD

COMPOUND EYES ............. . iv

II. "GENERAL. CHARACTERISTICS OF DECAPOD

COMPOUND EYES ............. . . vi

IIST OF FIGURES . . . . . . . . . . . . . . x

INTRODUCTION .................... 1

MATERIALS AND METHODS ............... . 4

I. ELECTRON MICROSCOPY : . . . . . . . . 4 4

II. IIGHT MICROSCOPY . . . . . . . . . 5

RESULTS . . . . . . . . . . . . . 7

I. GROSS MORPHOLOGY . . . . . . . . . . 7

II. THE DIOPTRIC APPARATUS . . . . . . . . 7

III. THE RETINULAR CELLS . . . . . . . . . 14

IV. THE DISTAL PIGMENT CELLS . . . . . . . . 17

V. THE TAPETAL CELLS . . . . . . . . . 19

VI. THE BASEMENT MEMbRANE . . . . . . . . . 22

VII. LIGHT- AND DARK-ADAPTATION . . . . . . . 22

VIII. EFFECTS OF PROLONGED DARKNESS . . . . . . 24

DISCUSSION . . . . . . . . . . . 26

REFERENCES CITED . . . . . . . . . . . . . 29 


\section{IIST OF FIGURES}

1. Diagrammatic representation of the ommatidial structure of the typical decapod compound eye of Callinectes ornatus . . viii

2. Adult male Hemigrapsus nudus . . . . . 8

3. A light-adapted eye in longitudinal section ............. 8

4. The edge of a light-adapted eye in longitudinal section .........

5. The dioptric apparatus in longitudinal section .............

6. Diagram of a longitudinal section of a light-adapted ommatidium of Hemigrapsus nudus . . . . . . . 10

7. The tip of the crystalline cone in longitudinal section .........

8. The crystalline cone in cross section...

9. The distal tip of the rhabdom and the proximal part of the crystalline cone in longitudinal section .......

10. The retinula in cross section. . . . . 15

11. The rhabdom in longitudinal section . . . 16

12. The distal part of the rhabdom in cross section ........... . 18

13. The proximal region of the retinulae (R) in longitudinal section....... 20

14. The distal part of the crystalline cone in longitudinal section . . . . . . 
15. An array of ommatidia in cross section . . 21

16. Oblique section of the rhabdom of a crab which had been in darkness for 146 


\section{INTRODUCTION}

It is widely accepted that the rhabdomeric microvilli are the location of visual pigment in compound eyes (Eakin, 1972). If microvilli are the site of the reaction with 1ight, their occurrence and orientation are central to an understanding of such phenomena as visual acuity and the perception of polarized light. Detailed structural analysis of compound eyes is a necessary correlate of functional analysis.

The most thoroughly studied Crustacea are the decapods, and usually eye morphoiogy conforms to the typical pattern described in the Preface. Exceptions to this pattern occur, notably the spiny lobster, Panulirus, which has a proximal section of the ommatidium in which microvilli form an intracellular rhabdomere around a cytoplasmic core, and in which microvilli extend in all directions perpendicular to the optic axis (Eguchi and Waterman, 1966).

The purpose of the present investigation is to extend the structural basis for interpretation of the function of the compound eye by a light and electron microscopic. study of the structure of the compound eye of the purple shore crab, Hemigrapsus nudus Dana, 1851. The eye of this brachyuran has not been described in detail, although 
Smith (1948) has discussed its gross morphology in the context of pigment migration.

Evidence for the photoreactive nature of the microvillous membranes comes from studies on the effects ưpon them of intense illumination and prolonged darkness. Rohlich (1967) has reported a profound disintegration of microvilli in the flatworm Dugesia tigrina after three weeks in darkness. Both glutaraldehyde and osmium tetroxide fixation were used. Similar results have been reported for the arthropod Ligia oceanica after two weeks in darkness and with glutaraldehyde fixation (Edwards, 1969).

Kabuta, Tominaga and Kuwabara (1.968) studied a number of arthropods and discovered occasional disorder of microvilli in control animals fixed with osmium tetroxide. After 247 days in darkness, Procambarus clarkii showed normal microvilli when fixed with glutaraldehyde. Normal microvilli were found in Artemia salina similarly fixed after three months in darkness. These investigators concluded that microvillous disintegration is an artifact of osmium fixation. However, Eguchi and Waterman (1966) tested Procambarus clarkii and Artemia salina after three months in darkness and with glutaraldehyde fixation. They found the microvillous pattern strongly disturbed or destroyed.

These results cannot be reconciled without additional 
work. As an adjunct to the morphological study of $\mathrm{H}$. nudus, crabs were kept in prolonged darkness and fixed with glutaraldehyde to check for microvillous disintegration. 


\section{MATERIALS AND METHODS}

Crabs were collected from rocky areas on the oregon coast at Garibaldi, Cape Lookout, Netarts, Newport and Brookings. They were kept in glass dishes in a cold room $\left(55^{\circ} \mathrm{F}.\right)$ with a light cycle of 12 hours on and 12 hours off. The crabs were fed pieces of mussel approximately weekly, and water was changed at least every third day. Unless otherwise noted, the morphological data were gathered from eyes which were fixed within three days after the crabs were collected.

To effect light-adaptation crabs were kept in glass containers which were placed on white paper in diffuse sunlight for at least three hours before fixation. Animals kept in prolonged darkness were in a container within an opaque fiberglass tub with a tight lid. Feeding, changing of water, and primary fixation were carried out in a darkroom under a red light. Normal dark-adapted eyes were also fixed in red light. To avoid effects of diurnal rhythms, fixation of normal light-adapted crabs was at 3:00 PM; fixation for normal dark-adapted eyes was at 10:00 PM.

\section{ELECTRON MICROSCOPY}

Whole eyes were severed just proximal to the compound 
eye itself and immediately immersed in fixative. The most successful fixative was: $5 \%^{\circ}$ formalin (from paraformaldehyde), $0.75 \%$ glutaraldehyde, $3 \% \mathrm{NaCl}$ and $3.5 \%$ sucrose with $0.66 \mathrm{M}$ phospate buffer at $\mathrm{pH} 7.2$ (Fahrenbach, 1973). Tissue was fixed for 10 to 17 hours and was then rinsed three times (15 minutes each) with buffer. Some of the eyes, expecially those of crabs over $20 \mathrm{~mm}$ in carapace width, were then dissected, to aid penetration of the osmium postfixative. After a fourth (one-hour) rinse in buffer, the eyes were postfixed in $1 \%$ osmlum tetroxide in an ice bath. The tissue was then rinsed four times (15 minutes each) with cold buffer, dehydrated"with alcohol, and embedded in Epon. Thin sections (about $90 \mathrm{~nm}$ ) were cut on a Porțer-Blum MT-1 ultramicrotome with glass knives made on an LKB knifemaker. Sections were picked up on uncoated 300 mesh grids, stained with lead citrate and uranyl acetate, and observed with a Zeiss EM9S-2 Electron Microscope.

\section{IIGHT MICROSCOPY}

Fixation for most of the light miscroscopy followed the above description. One $\mu \mathrm{m}$ sections were stained with toluidine blue and counterstained with basic fuchsin (Humphrey and Pittman, I"973). Cover slips were mounted with embedding rèsin.

For the light microscope work on light- and dark- 
adaptation, the crabs were immersed in $80^{\circ} \mathrm{C}$. water for 15 seconds, then the eyes were removed, dehydrated, and embedded in paraffin (Welsh, 1930). Ten um sections were stained with Mallory's triple stain, Ehrlich's acid hematoxylin and eosin, or were observed without staining. 


\section{RESULTS}

\section{GROSS MORPHOLOGY}

The movable eyestalks of $\underline{\mathrm{H}}$. nudus are held laterally $60^{\circ}$ from the horizontal axis of the crab when it is active (Fig. 2). The ommatidial array covers the anterior distal part of the eyestalk and extends around the eyestalk tip except for a posterior dorsal section. The ommatidia vary in length with location in the eye and with the size of the crab. Morphological data are taken from sections made at the center of the anterior part of the eye when it is held erect. Measurements are from light-adapted crabs 19$21 \mathrm{~mm}$ across the widest part of the carapace. A longitudinal section of the whole eye shows the ommatidia arranged in an arc, with shorter ommatidia at the ends of the arc and the longest ommatidia at the center (Fig. 3). At the boundary of the array are cells filled with pigment granules (Fig. 4). Measured from the tip of the crystalline cone to the basement membrane, ommatidia vary from $200 \mu \mathrm{m}$ at the edge to $350 \mu \mathrm{m}$ at the center of the eye.

II. THE DIOPTRIC APPARATUS

The transparent corneal lens, 30-60 $\mu \mathrm{m}$ thick, has almost no external sculpturing (Wolf H. Fahrenbach, 


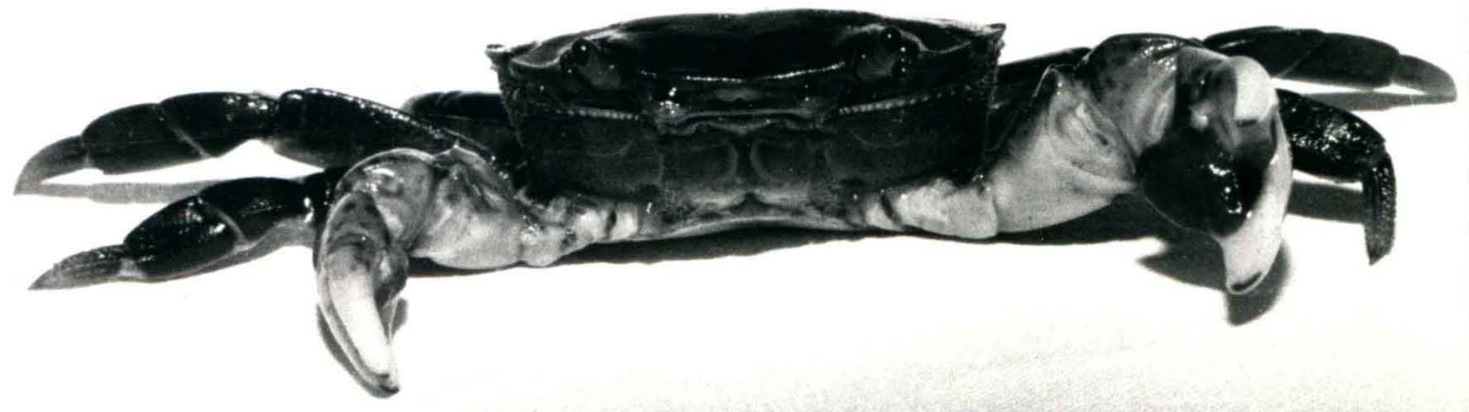

Figure 2. Adult male Hemigrapsus nudus. Notice the characteristic position of the eyestalks relative to the body. $2.5 \mathrm{x}$

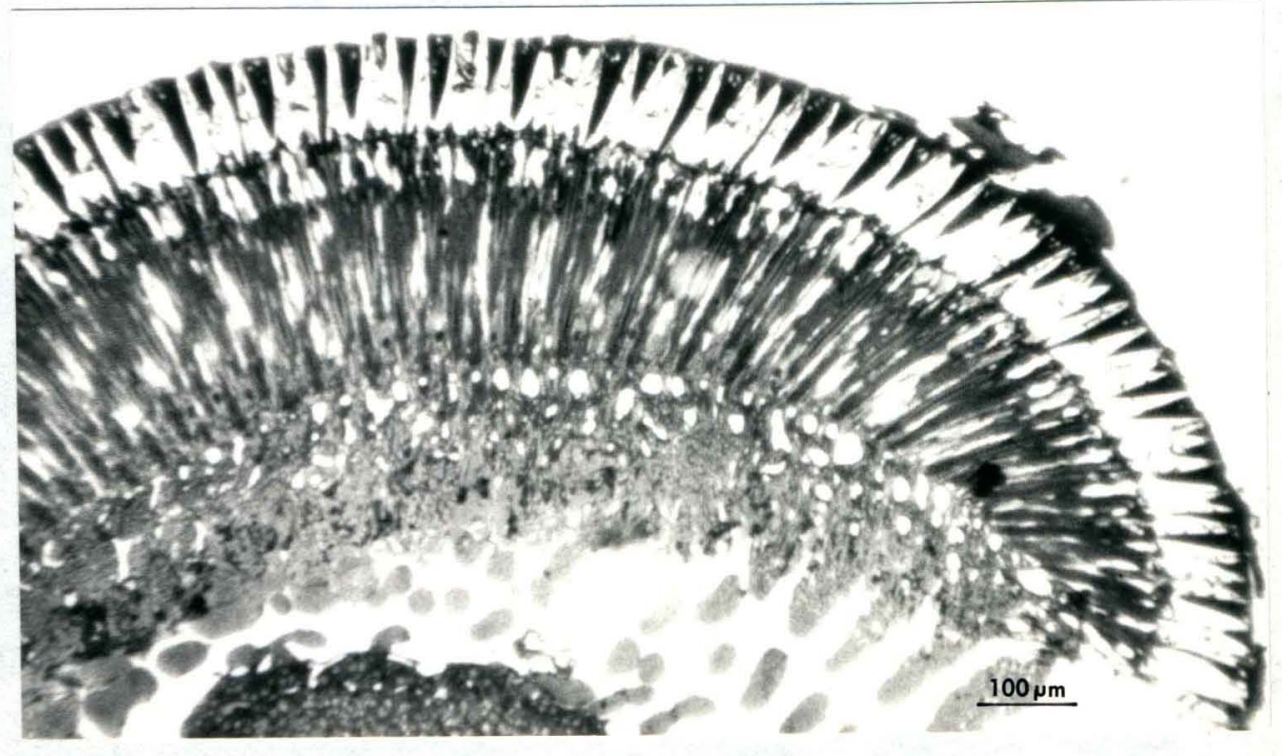

Figure 3. A light-adapted eye in longitudinal section. The ommatidia vary in length from the edge to the center of the eye. The cuticle has been torn away. 


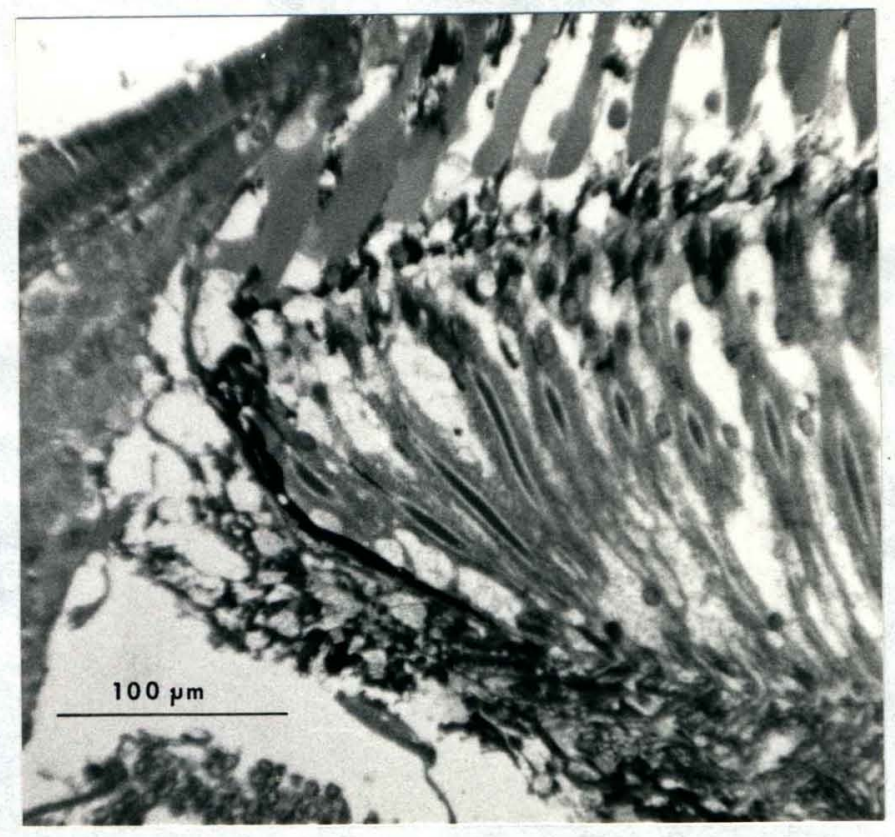

Figure 4. The edge of a light-adapted eye in longituainal section. The pigment filled boundary can be seen.

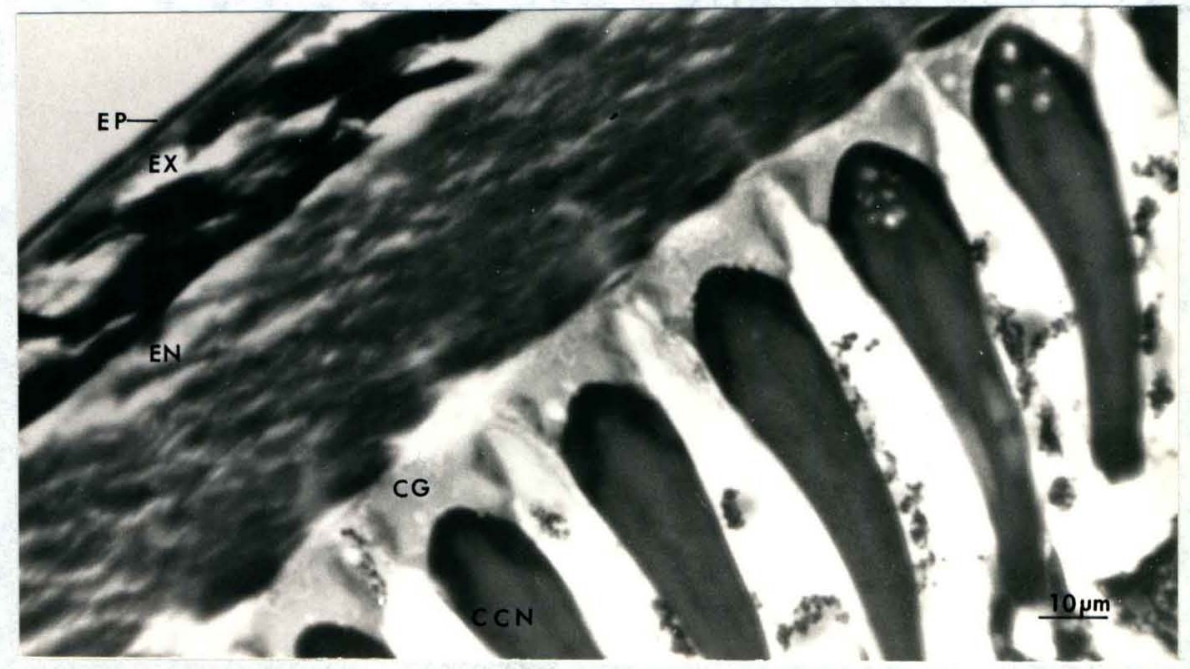

Figure 5. The dioptric apparatus in longitudinal section. The epicuticle (EP), exocuticle (EX), and endocuticle (EN) lie over the corneagenous cells (CG) and crystalline cone (CCN). 


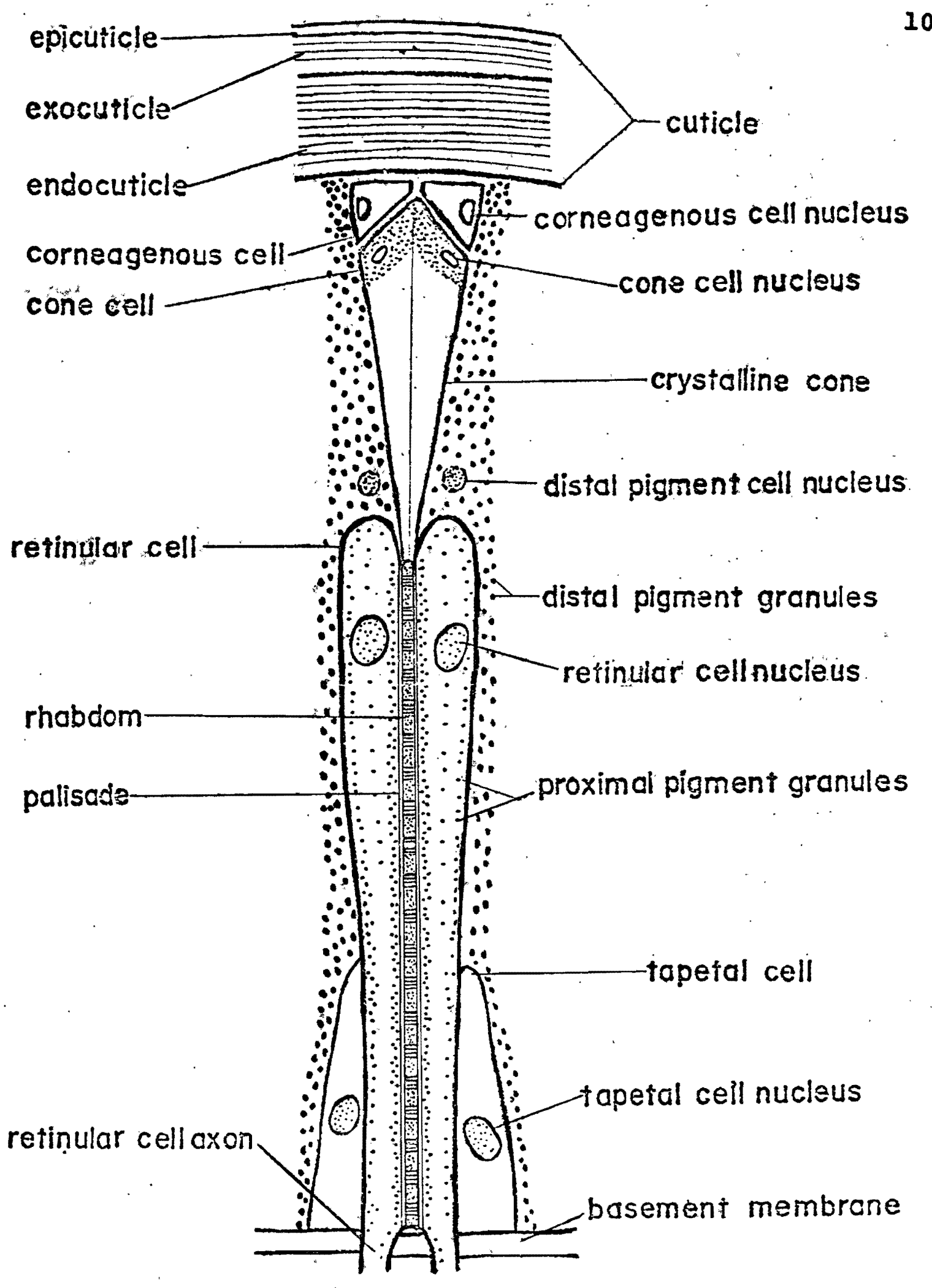

Figure 6. Diagram of a longitudinal section of a light-adapted ommatidium of Hemigrapsus nudus. 
personal communication). Three regions of the cuticle can be distinguished: a thin epicuticle (28), a thicker exocuticle (34\%), and a thick endocuticle. (64\%)..$^{1}$ The endocuticle and exocuticle are lamellate. The outer surface is slightly convex; the inner surface is flat or is parallel to the outer surface (Fig. 5 and 6).

In longitudinal section the wedge shaped corneagenous cells resemble two triangular bodies with one edge along the cuticle and a second edge, approximately at right angles to the first, parallel to the longitudinal axis of the omnatidium. The nucleus lies close to this edge. The third edge is curved against the cone cells (Fig. 5, 6 and 7). The crystalline cone is composed of intracellular secretions from four cone cells (Fig. 6, 7 and 8). These cone cells stain more darkly than the crystalline cone itself. The cone cell nucleus is at the periphery of the widest part of the cone (Fig. 6 and 7). Proximally, the crystalline cone tapers and fits like a socket over the distal end of the rhabdom (Fig. 6 and 9). Four crystalline cone processes extend toward the basement membrane between retinular cells (Fig. 10). Their proximal terminus is not known.

1 Since the cuticle thickness varies and the relative proportions of the regions are constant, figures given are for percent of total cuticle thickness. 


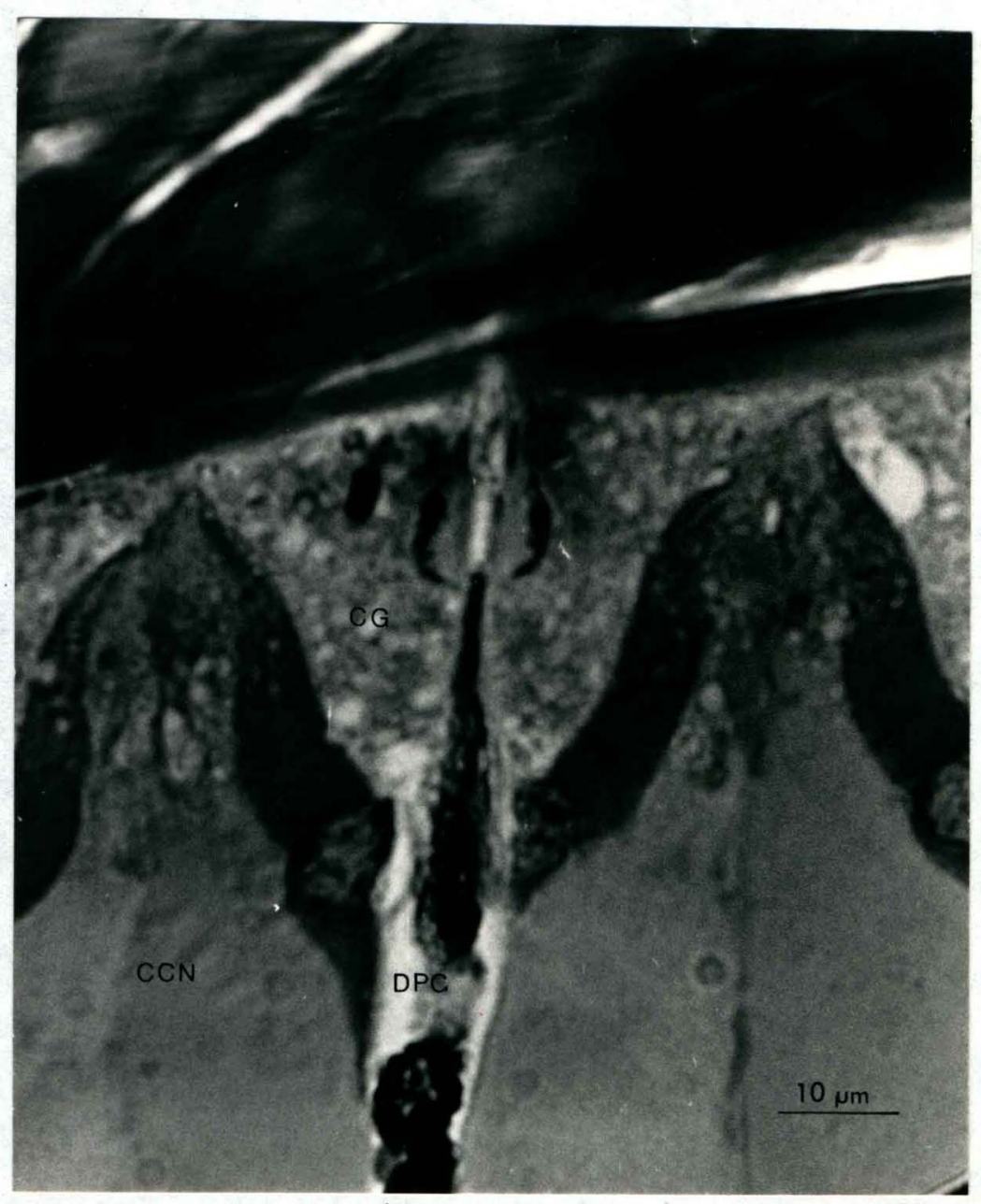

Figure 7. The tip of the crystalline cone in longitudinal section. Corneagenous cells (CG) and the dark staining portion of the cone cells (CC) lie between the cuticle and the crystalline cone (CCN). The distal pigment cell (DPC) contacts the cuticle between corneagenous cells of adjacent ommatidia. 


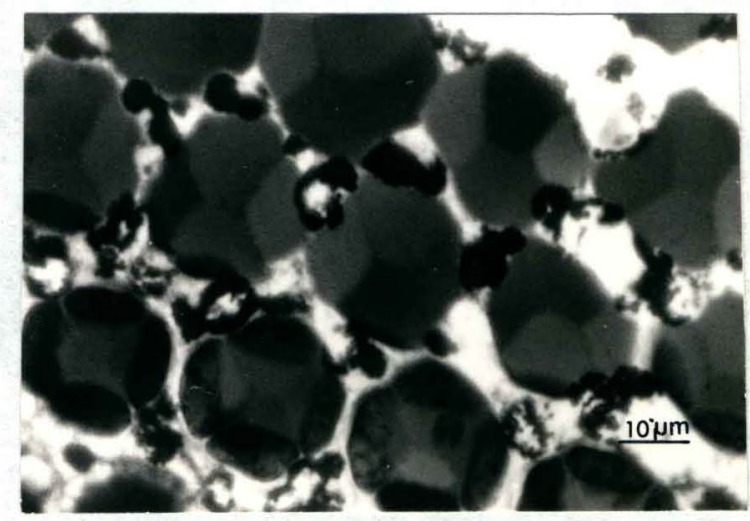

Figure 8. The crystalline cone in cross section. The four-part structure is clear. At the lower left are the four darkly staining parts of the cone cells. Distal pigment granules can be seen between cones.

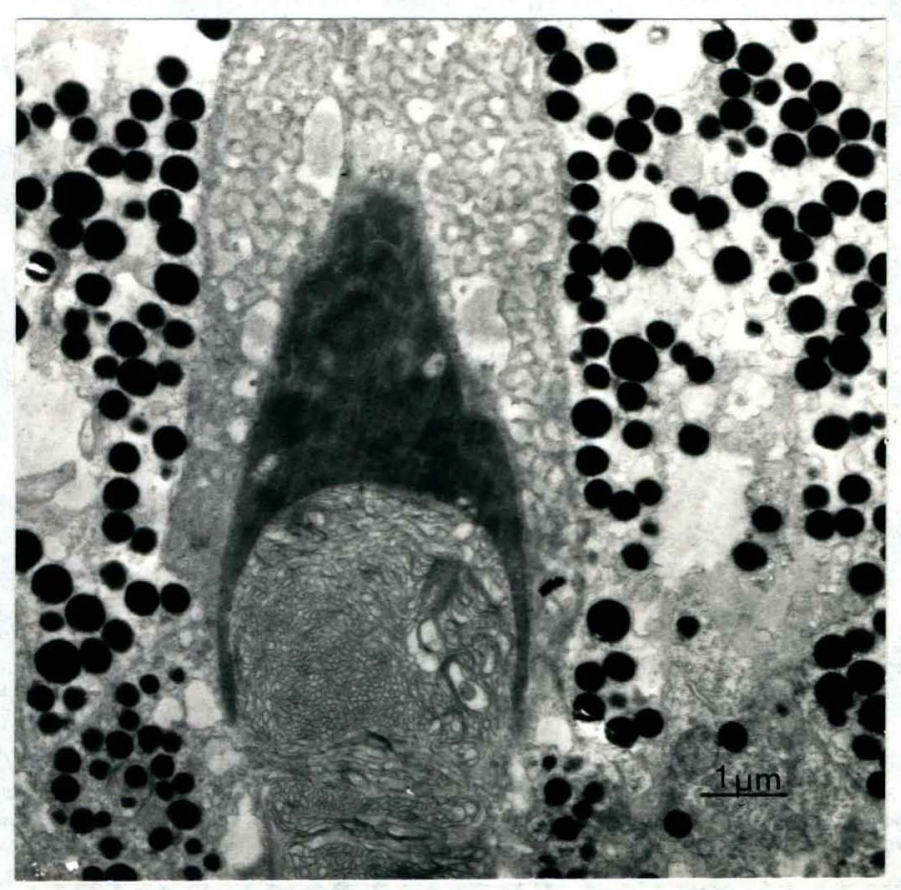

Figure 9. The distal tip of the rhabdom and the proximal part of the crystalline cone in longitudinal section. 
III. THE RETINULAR CELLS

The fused type rhabdom abuts against the crystalline cone proximally and extends to the basement membrane. It

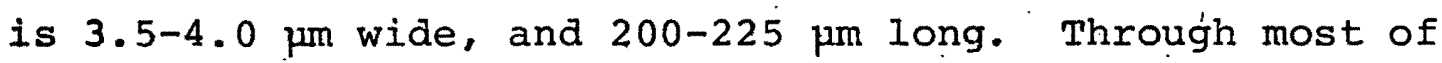
the length of the ommatidium, rhabdomeres from seven retinular cells make up the rhabdom. There are two groups of retinular cells: 1) the first has three cells, with cell number 1 contributing a large rhabdomere on one side and cells number 4 and 5 each contributing a rhabdomere half as large on the opposite side; 2) the other group consists of cells number $2,3,6$ and 7 , each of which contributes one quarter of the rhabdom cross section (Fig. 1 and 10). ${ }^{2}$ Layers of microvilli from the two groups of retinular cells alternate. The layers are oriented at right angles to each other (Fig. 11).

The palisade is prominent, and pigment granules, multivesicular bocies, and lamellar bodies are present in the retinular cells. The nucleus lies in the distal third of the cell (Fig. 5). Adhering junctions occur at the point of juncture of the rhabdom and adjacent cells (Fig. 10).

Distally there is probably an eighth retinular cell.

2 The numbering, system is that used by Eguchi (1965) and Eguchi and Waterman (1966). 


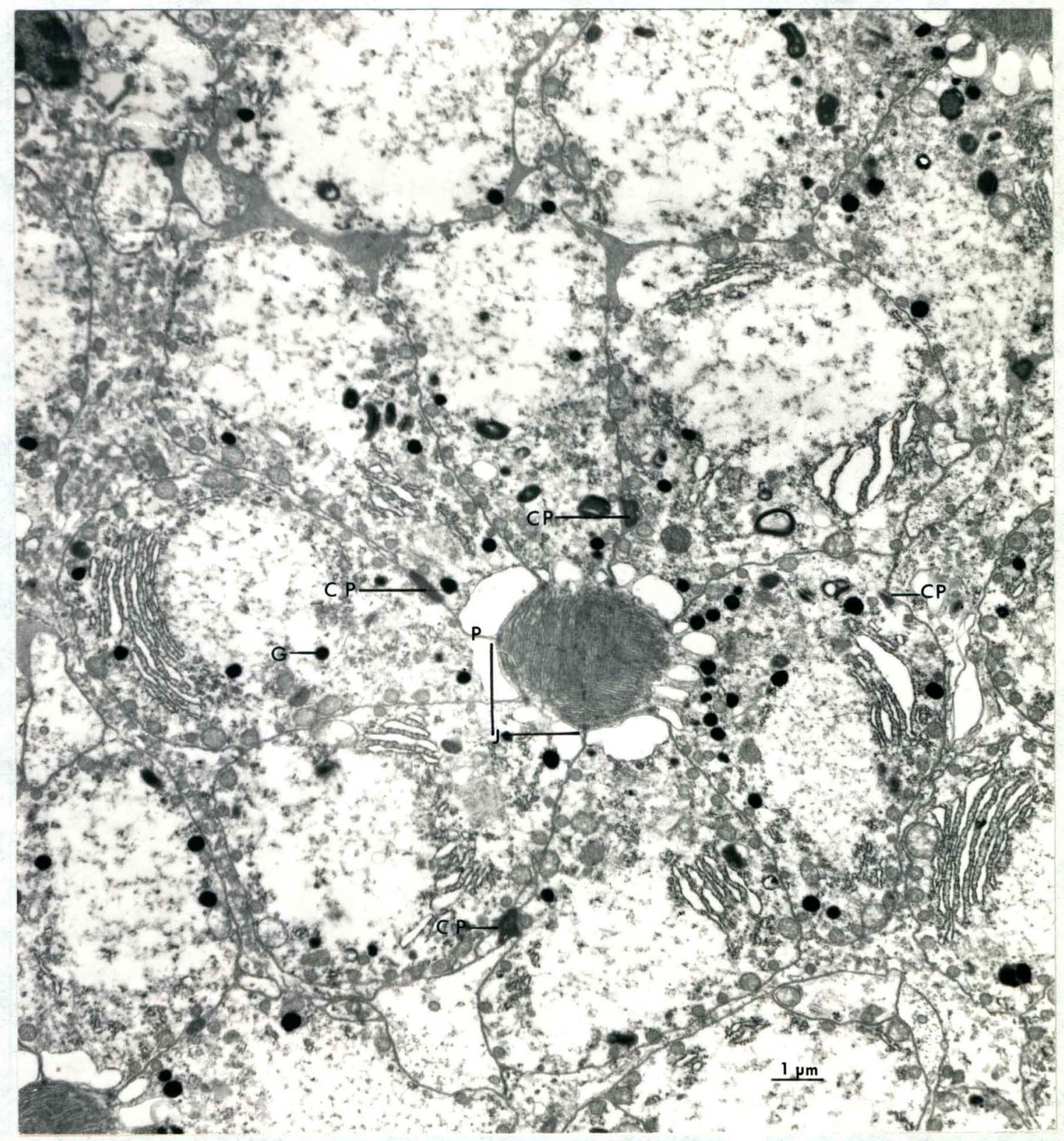

Figure 10. The retinula in cross section. In this light adapted eye, the proximal pigment granules (G) occur at the cell periphery or adjacent to the palisade (P). Intermediate junctions $(\mathrm{J})$ mark the place where adjacent retinular cells contact the rhabdom. Four crystalline cone cell processes (CP) can be seen. 


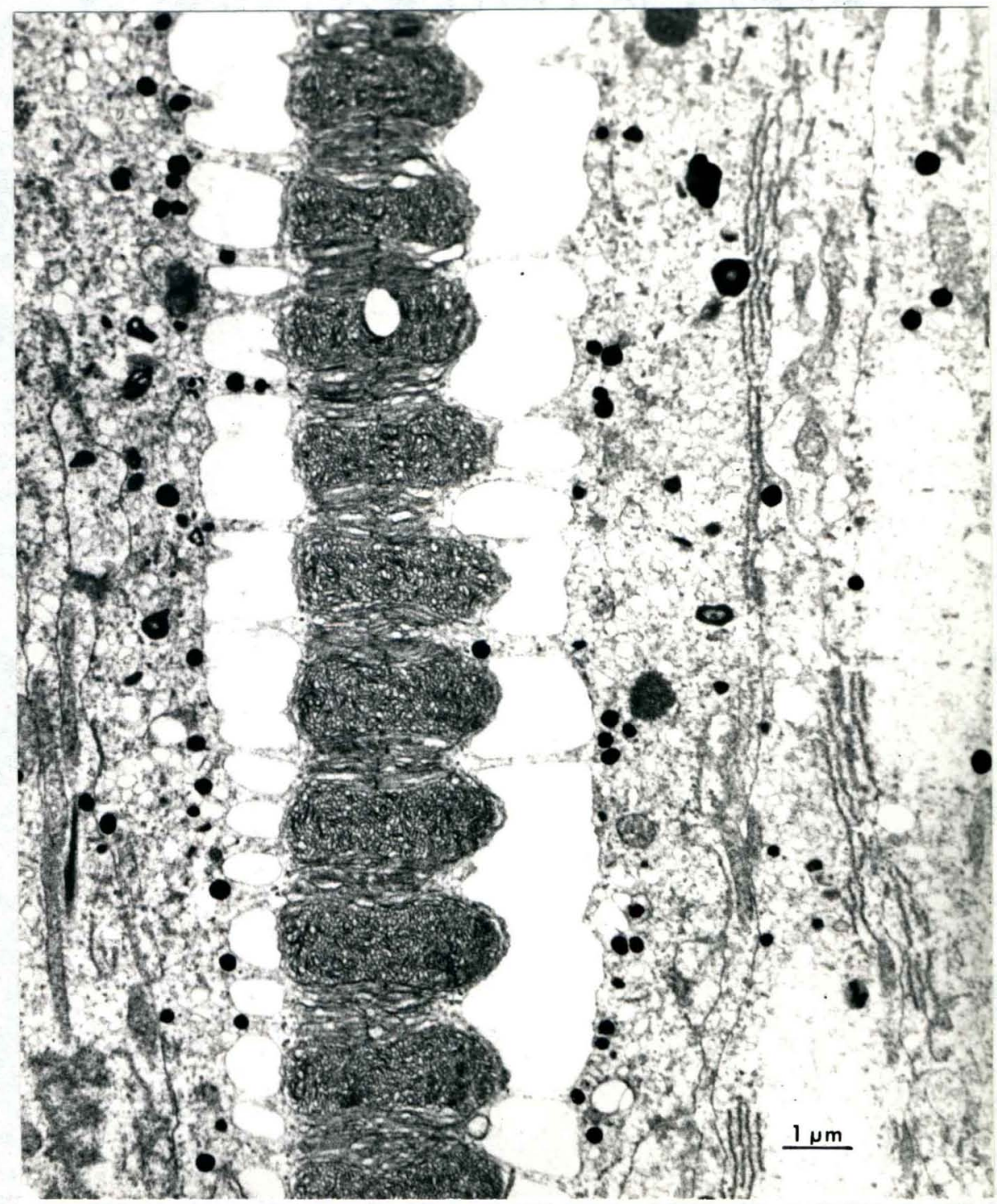

Figure 11. The rhabdom in longitudinal section. Microvilli occur in mutually perpendicular Jayers. 
In Grapsus (Eguchi and Waterman, 1973) and in Ocypode cursor (Kunze, 1967) a distal four-lobed cell with the nucleus in the largest lobe and with no pigment granules has been described. Eguchi and Waterman state and Kunze suggests that this structure is an eighth retinular cell. A similar structure was found in distal sections of the ommatidia of H. nudus (Fig. 12).

Proximally the retinular cell axons cross the basement membrane. Axons from one ommatidium do not form a single bundle; rather, some of the axons from adjacent ommatidia extend slightly laterally and penetrate the basement membrane together (Fig. 13).

IV. THE DISTAL PIGMENT CELLS

None of the fixation techniques used satisfactorily preserved the distal pigment cells. Loss of detail was especially marked in the area between the crystalline cones where they taper toward the rhabdom. Some generalizations, however, can be made. Distal pigment cells surround the crystalline cone and extend from the corneal lens (between corneagenous cells) proximally (Fig. 6 and 15). Near the juncture of the cone and the rhabdom, the distal pigment cells form narrow shafts which extend beside the retinular cells to the basement membrane. The nucleus appears to be near the proximal end of the crystalline cone. A problem 


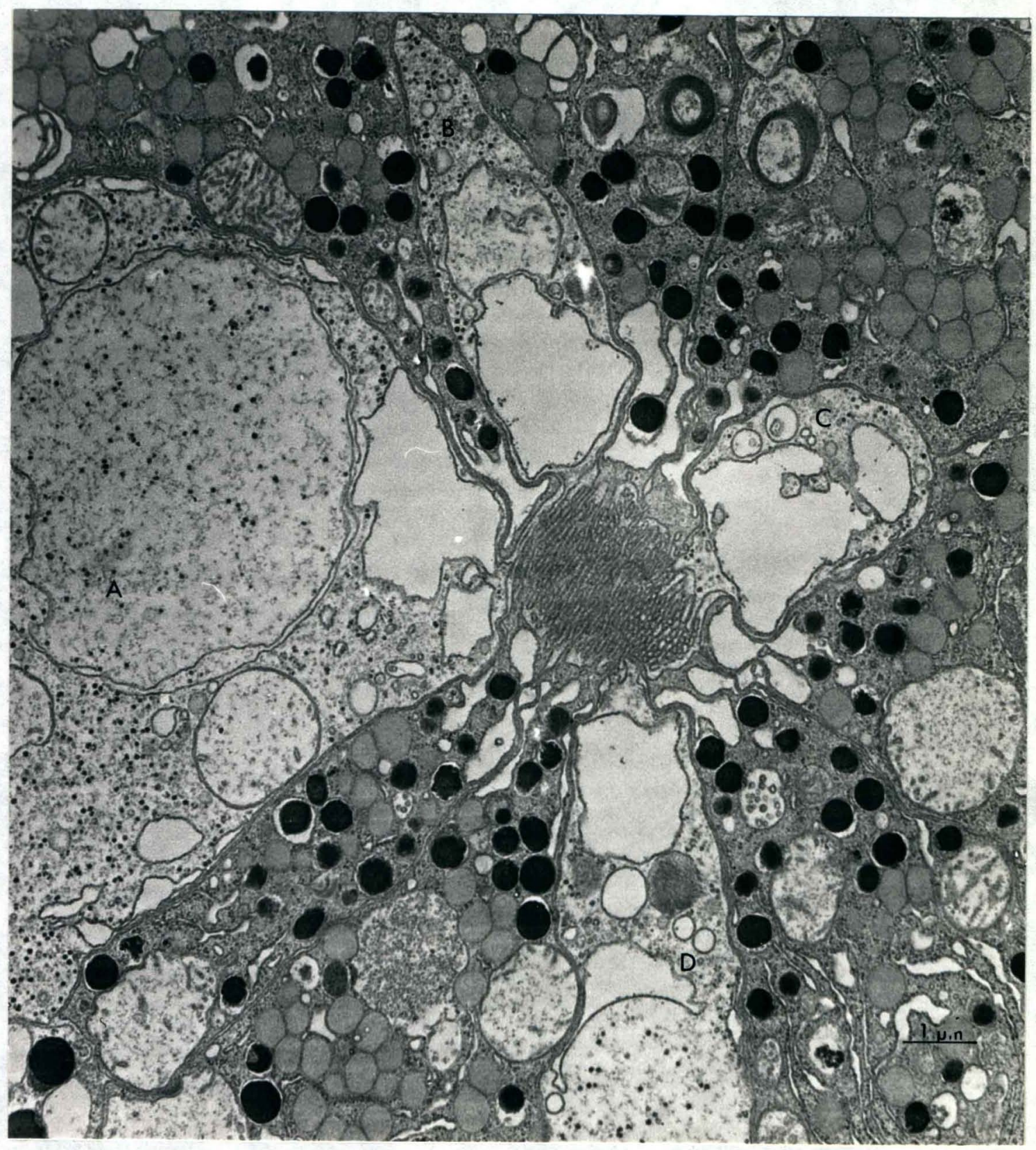

Figure 12. The distal part of the rhabdom in cross section. The four areas with no pigment granules $(A, B, C$ and $D)$ compose the presumptive eighth retinular cell. (Fixed with 1\% glutaraldehyde in phosphate buffer followed by $1 \% 0_{4}$. Fixation was 3.5 days after the crabs were collected.) 
is the possibility that the distal pigment cells change shape or migrate with fluctuations in light intensity, as they do in Palaemonetes (Welsh, 1930). Since detail is lost in fixation, the distal cell boundaries have been estimated by the position of pigment granules (Fig. 14). Changes in cell shape may have been obscured.

As a consequence of close packing, each ommatidium is surrounded by six others. If each ommatidium has two distal pigment cells shielding its retinula, the aggregation results in a distribution of six distal pigment cells around each retinula (Fig. 15) which are sometimes deflected from a straight line proximally by tapetal cells.

\section{THE TAPETAL CELLS}

Clear cells with a large nucieus extend distally between retinulae approximately $60 \mu \mathrm{m}$ from the basement membrane. They taper from 10-12 $\mu \mathrm{m}$ wide at the basement membrane to a narrow distal tip. Since these cells are possibly the site of the reflecting pigment, fresh preparations were viewed with crossed polarizing filters to determine whether they contained birefringent crystalline structures. The area around the proximal third of the retinulae showed weak birefringence. Unstained paraffin sections which had been fixed in $80^{\circ} \mathrm{C}$. water were viewed with dark field illumination. The area occupied by these 


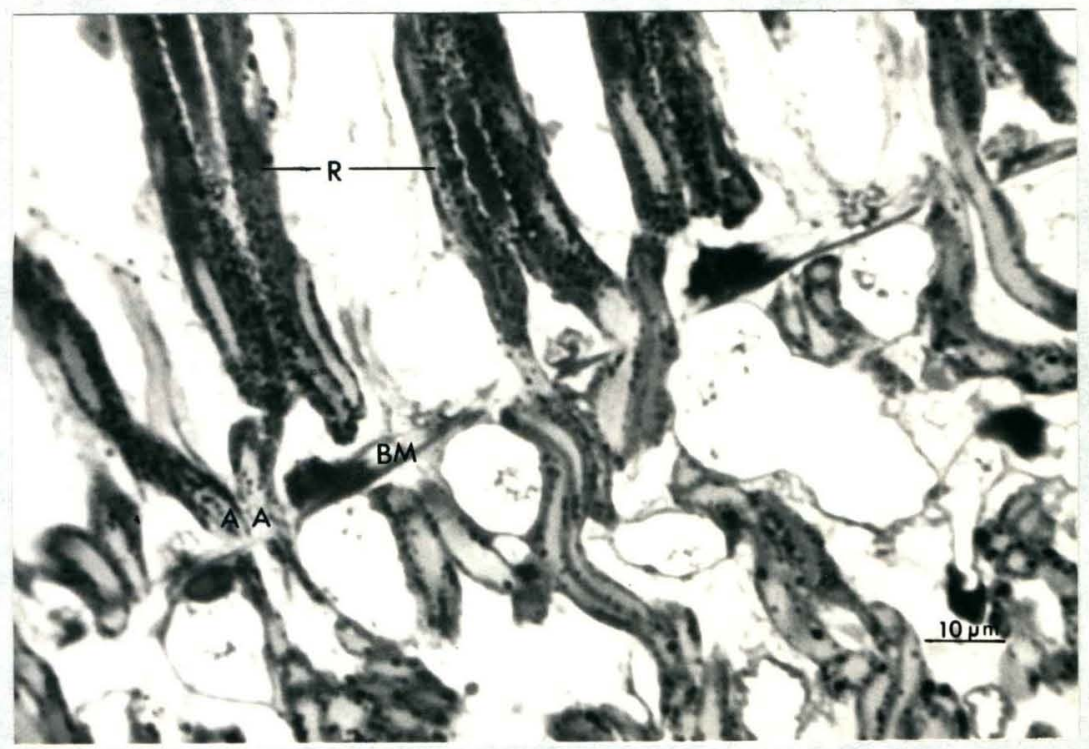

Figure 13. The proximal region of the retinulae (R) in longitudinal section. Axons (A) from neighboring retinulae cross the basement membrane (BM) together.

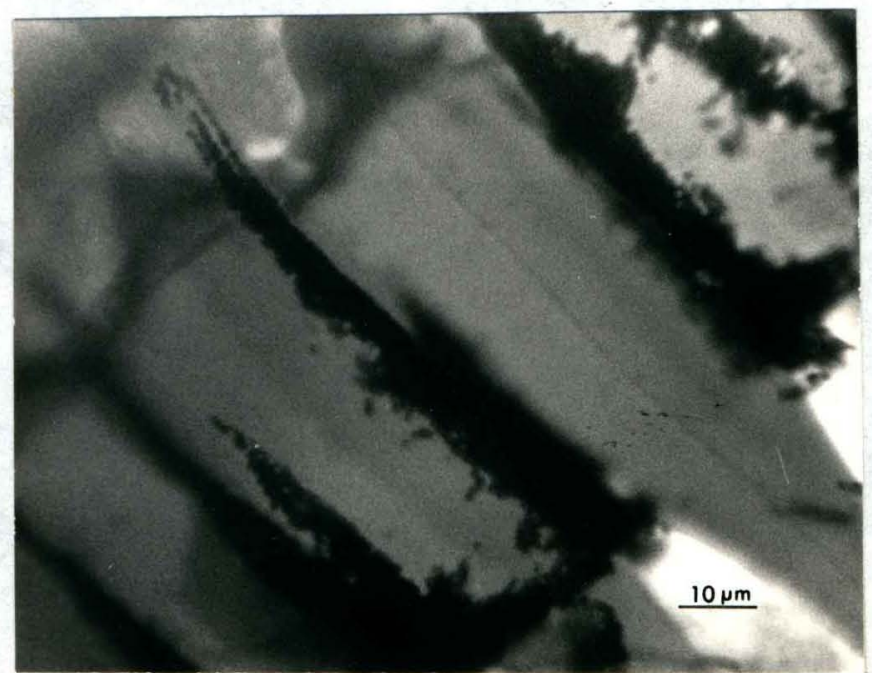

Figure 14. The distal part of the crystalline cone in longitudinal section. The distal pigment granules indicate the position of the distal pigment cells. 


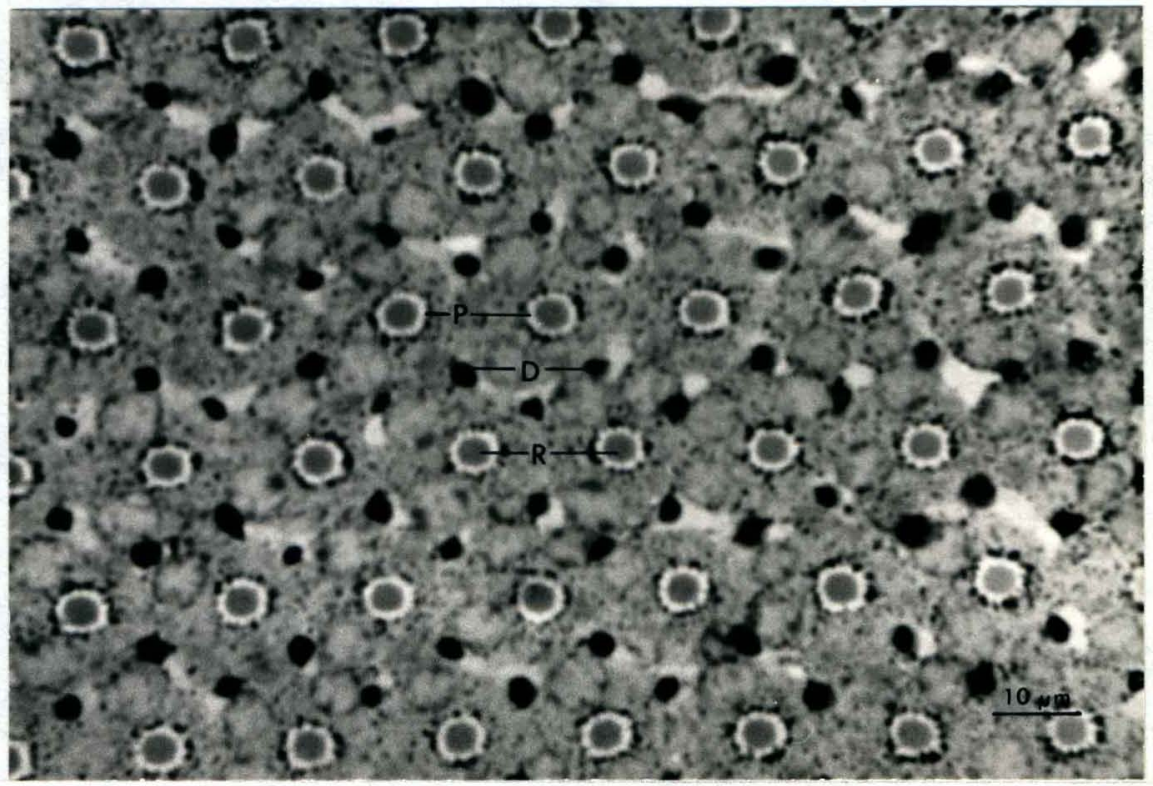

Figure 15. An array of ommatidia in cross section. Each retinula is surrounded by distal pigment cells from surrounding ommatidia. The gray circles surrounded by a clear space are the rhabdom (R) and the palisade (P) respectively. The very dark spots are the distal pigment cells (D). 
cells. glowed strongly in the dark-adapted eye. Because of their presumptive reflective function, these cells are designated tapetal.

\section{THE BASEMENT MEMBRANE}

The basement membrane, about 2 pm thick, lies under all the ommatidia. It is filbrillar, thicker at the base of each rhabdom than between retinulae, and is penetrated by retinular cell axons (Fig. 13).

\section{IIGHT- AND DARK-ADAPTATION}

In the light-adapted state, the distal pigment sometimes extends from the cuticle to the basement membrane. More often it is found proximally only to within 50-75 $\mathrm{mm}$ of the basement membrane. In dark-adaptation, the distal pigment is concentrated around the proximal end of the crystalline cone.

The proximal pigment granules are retinular cell inclusions. These granules extend the length of the rhabdom in the light-adapted eye. They are found at the periphery of the retinular cell in cross-section (Fig. 10) and are most numerous adjacent to the perirhabdomal vacuoles. In dark-adaptation, the proximal pigment granules are concentrated proximally.

In light-adapted eyes, the reflecting pigment is withdrawn proximally below the basement membrane. In dark- 
adapted eyes it lies along the proximal third of the retinula. As has been suggested above, it probably is contained in the tapetal cells (Fig. 6).

In the locust (Horridge and Barnard, 19.65), the palisade disappears in light-adapted eyes. In a crab, Libinia, Eguchi and waterman (1967) found greatest palisade development in därk-adapted animals after 17 hours of aarkness. They found no difference in the palisade between ieyes subject to 5 hours of darkness, 5 hours of light, or 17 hours of light. "They did find that the palisade was smaller proximally than in the distal rhabdom.

In $\mathrm{H}$. nudus the palisade is slightly larger relative to the size of the riabdom in the distal part of the eye (Fig. 12) than in a more proximal section (Fig. 10). The palisade does not disappear in the light-adapted eye.

The crystalline cone is easily stretched or collapsed in fixation and sectioning. Also, the juncture between the cone and the rhabdom is obscured by distal pigment granules in dark-adapted eyes. Twelve light-adapted and 12 darkadapted ommatidia were measured in eyes in which there was no obvious distortion, and in which the proximal end of the crystalline cone was visible. In light-adapted eyes, the crystalline cone composed $35.0 \%$ of the length; in darkadapted eyes it composed $28.2 \%$ of the length. At the center of the eye this would be a difference of up to $24 \mathrm{\mu m}$. 
The tapered proximal part of the crystalline cone looks more "stubby" as well.

VIII. EFFECTS OF PROLONGED DARKNESS

Crabs were kept in an opaque container for 146 days. After fixation with glutaraldehyde they showed a regulair array of microvilli in layers oriented at right angles to each other (Fig. 16). 


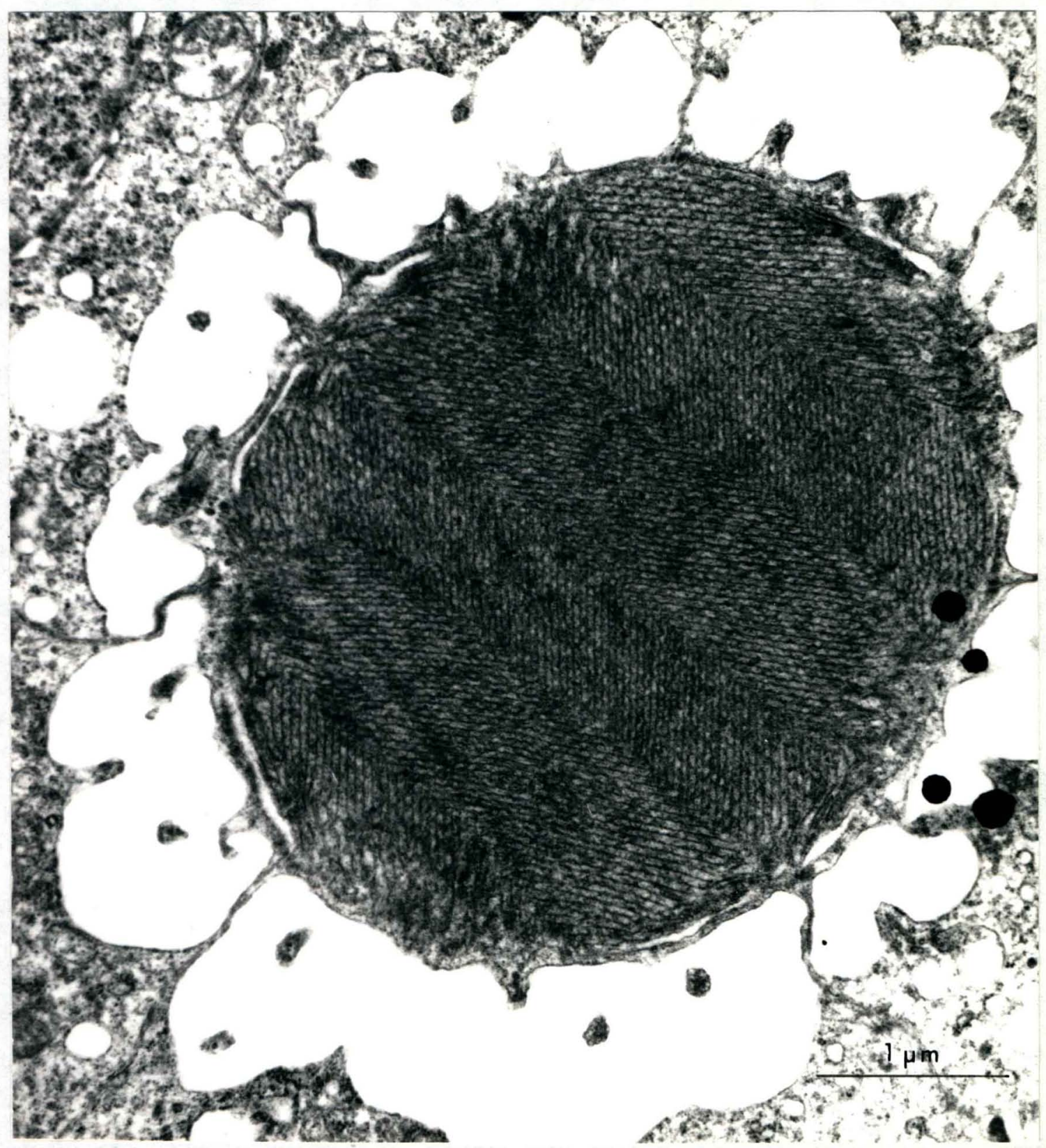

Figure 16. Oblique section of the rhabdom of a crab which had been in darkness for 146 days. The microvilli do not show disintegration. 


\section{DISCUSSION}

The eye of $\mathrm{H}$. nudus conforms to the pattern tyjpical of decâpod Erustacea. Microvilli are layered in a single, fused rhabdom as in Callinectes (Eguchi and Waterman, (1966). There is probably a distal eighth retinular cell as in Grapsus (Eguchi and Waterman, 1972) and Ocypode (Kunze, 1967). The palisade is persistent in lightadaptation as in Iibinia (Eguchi and Waterman, 1967). The microvilli do not depend upon light for structural integrity. The persistence of regularly arranged microvilii after 146 days in darkness supports the conclusion of Kabuta, Tominaga, and Kuwabara (1968) that such effects are artifactual.

The crystalline cone shows some plasticity. A crystalline tract which extends with light-adaptation and contracts with dark-adaptation has been described for neuropteran eyes in beetles by Horridge and Giddings (1971). The effect in H. nudus may be due to fixation or sectioning. If it is not artifactual, it may be a passive movement on the part of the crystalline cone in response to movement of the retinula. Burtt and Catton (1966) suggest that the lens, without the cone, focuses an image at the tip of the rhabdom. If this is the case, the cone 
may act as a spacer. The shorter cone in the dark-adapted eye may allow more light to fall on the rhabdom.

The eighth retinular cell is presumed to be one cell by Eguchi and Waterman (1973) because the four lobes only have one nucleus and one axon. The nucleus associated with the presumptive eighth retinular cell was not seen in $\mathrm{H}$. nudus but the distal part of the retinula in cross section showed only one axon associated with the seven proximal retinular cells. Further evidence is the location of the four lobes, with the largest next to retinular cell number 1 , and their lack of pigment granules.

Most studies of dark- and light-adaptation are done under artificially intense conditions. H. nưdus lives under rocks during the day and forages at night on the beach. It does not move about in bright, light; it seldom experiences as many as 17 hours of darkness.

The fused rhabdom greatly increases the light absorbing area in the eye (Shaw, 1969b). Shaw (1969b) also suggests that the primary function of microvilli oriented at right angles to the ommatidial axis is to concentrate the visual pigment in the light path. Both of these advantages would be important to an animal which lives in twilight.

The persistent palisade may enhance the light guide properties of the rhabdom. This would increase the opportunity for absorption by visual pigments in dim light. 
The ommatidium has been widely regarded as the functional unit of the compound eye. The morphology of the retinular cells suggest that individual. structures within the ommatidium can gather, transduce and transmit information about radiant-energy from the environment. Alternate layers of microvilli provide a physical basis for orientation of the visual pigment, and therefore can be interpreted as the structural foundation for polarized light perception (waterman and Horsch, 1966; Eguchi and Waterman, 1967). 'In this case, each group of retinular cells would constitute a functional unit. The advantages of polarized light perception to $\mathrm{H}$. nudus are not clear since the animal is most active at night.

Eguchi and Waterman (1973) suggested that the eighth retinular cell has a lower threshold to dim unpolarized light than the rest of the rhabdom. Since this cell lies in the area of the rhabdom upon which an image is focused by the dioptric apparatus (Kuiper, 1966), an alternative is that these cells function in image transmission in the traditional sense of a mosaic.

An image triggering an individual response in each ommatidium would explain the extreme responsiveness to movement in the visual field which is typical of animals with compound eyes. Since shore birds are major predators of H. nudus, this sensitivity to movement is of great adaptive value. 


\section{REFERENCES CITED}

Bullock, T.H. and G.A. Horridge: Arthropoda: Receptors for light and the optic lobe. In: Structure and function in the nervous systems of invertebrates. Vol. II, San Francisco and London: Freeman 1965.

Burkhardt, D., I. de la Molle, and G. Seitz: The physiological optics of the compound eye of the blow fly. In: The functional organization of the compound eye. Oxford-New York: Pergamon Press 1966.

Burtt, E.T. and W.T. Catton: The role of diffraction in compound eye vision. In: The functional organization of the compound eye. oxford-New York: Pergamon Press 1966.

Eakin, R.M.: Structure of invertebrate photoreceptors. In: Handbook of sẹnsory physiology Vol. VII/I Phatochemistry of vision. (DartnelI, H.J.A.. Ed.) Heidelberg-New York: Springer-Verlag 1972.

Edwards, A.S.: The structure of the eye of Ligia oceanica I. Tissue and Cell. 1 (2), $\overline{217-228}$ (1969).

Eguchi, E.: Rhabdom structure and receptor potentials in single crayfish retinular cells. J. Cell. Comp. Physiol. 66, 411-429 (1965).

Eguchi, E. and T.H. Waterman: Fine/structure patterns in crustacean rhabdoms. In: The functional organization of the compound eye. Oxford-New York: Pergamon Press 1966.

Eguchi, E. and T.H. Waterman: Changes in retinal fine structure induced in the crab Iibinia by light and dark adaptation. Z. Zellforsch. 79, 209-229 (1967).

Eguchi, E. and T.H. Waterman: Orthogonal microvillus pattern in the eighth rhabdomere of the rock crab, Grapsus. Z. Zeliforsch. 137, 145-157 (1973).

Eguchi, E., T.H. Waterman, and J. Akiyama: Localization of the violet and yellow receptor cells in the crayfish retinula. J. gen. Physiol. 62, 355-374. (1973). 
Fahrenbach, W.H.: The morphology of the Limulus visual system V. Protocerebral neurasecretion and ocular innervation. Z. Zellforsch 144, 153-166 (1973).

Goldsmith, T.H.: The visual system of insects. In: The physiology of insecta, Vol. 1 (Rockstein, M., Ed.). New York: Academic Press 1964.

Horridge, G.A. and P.B.T. Barnard: Movement of palisade in locust retinula cells when illuminated. Quart. J. Microsc. Şcience, 106, Pt. 2: 135-136 (1965).

Horridge, G.A. and C. Giddings: Movement on dark-light adaptation in beetle eyes of the neuropteran type. Proc. R. Soc. Lond. B. 179, 73-85 (1.971).

Humphrey, C.D. and F.E. Pittman: A simple Methylene BlueAzure II-Basic Fuschs in stain for epoxy embedded tissue sections. Stain Technology, 49, 9-14 (1974).

Kubuta, H., Y. Tominaga, and M. Kuwabara: The rhabdomeric microvilii of several arthropod compound eyes kept in darkness. Z. Zellforsch. 85, 78-88 (1968).

Kleinhoiz,.I.H.: Hormonal regulation of retinal pigment migration in crustaceans. In: The functional organization of the compound eye. Oxford-New York: Pergamon Press 1966.

Kuiper, J.W.: Image formation in a single ommatidium of the compound eye in Diptera. In: The functional organization of the compound eye. Oxford-New York: Pergamon Press 1966.

Kunze, P.: Histologisch Untersuchungen zum Bau des Auges von Ocypode cursor (Brachyura). Z. Zellforsch. 82,

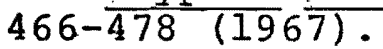

Millott, N.: The dermal light sense. Symp. Zool. Soc. Lond. 23, 1-36 (1968).

Röhlich, P.: Fine structural changes induced in photoreceptors by light and prolonged darkness. In: symp. on neurobiology of invertebrates. (Salanki, J., Ed.) New York: Plenum Press 1968.

Röhlich, P. and E. Tar: The effect of prolonged lightdeprivation on the fine structure of planarian photoreceptors. Z. Zellforsch. 90, 507-518 (1968). 
Röhlich, P. and I. Törö: Fine structure of the compound eye of Daphnia in normal, dark- and strongly lightadapted state. In: The structure of the eye. II. Symposium (Rohen; J.W., Ed.) Stuttgart: F.K. Schattauer-Verlag 1965.

Shaw, S.R.: Optics of arthropod compound eyes. Science $165,88-90$ (1969).

Shaw, S.R.: Sense-cell structure and interspecies comparisons of polarized-1ight absorption in arthropod compound eyes. Vision Res. 9, 1031-1040 (1969).

Smith, R.: The role of the sinus glands in retinal pigment migration in grapsoid crabs. Biol. Bull. 95, 169-185 (1948).

Waterman, T.H., H.R. Fernandez, and T.H. Goldsmith:

$*$ Dichroism of photosensitive pigment in rhabdoms of the crayfish Orconectes. J. gen. "Physiol. 54, 415-432 (1969).

Waterman, T.H. and K.W. Horsch: Mechanism of polarized light perception. Science, $154,467-475$ (1966).

Welsh, J.H.: The mechanics of migration of the distal pigment cells in the eyes of Palaemonetes. J. Expt1. Zool. 56, 459-494 (1930).

Wolken, J.J.: Invertebrate photoreceptors, a comparative analysis, New York: Academic Press 1971. 